\title{
PENGARUH DIHAPUSNYA STATUS RSBI TERHADAP MOTIVASI DAN PRESTASI BELAJAR SISWA SERTA PRESTASI KINERJA GURU DI SMA NEGERI 1 BANGLI
}

\author{
A.A. Istri Ririn Anjasmari, I Gusti Ketut Arya Sunu, \\ I Nyoman Pursika \\ Jurusan PPKn \\ Universitas Pendidikan Ganesha \\ Singaraja, Indonesia

\begin{abstract}
e-mail : \{istri ririn xi ipa2 36@yahoo.com, arya.sunu@pasca.undiksha.ac.id. pursika@ymail.com\}
\end{abstract}

\begin{abstract}
ABSTRAK
Penelitian ini bertujuan untuk mengetahui pengaruh dihapusnya status RSBI terhadap (1) motivasi belajar siswa; (2) prestasi belajar siswa; (3) prestasi kinerja guru di SMA Negeri 1 Bangli. Penelitian ini merupakan penelitian deskriptif kualitatif dengan strategi penelitian studi kasus. Tempat penelitian ini adalah SMA Negeri 1 Bangli yang dulu pernah menyandang status sekolah RSBI. Objek penelitian ini adalah (1) motivasi belajar siswa; (2) prestasi belajar siswa; (3) prestasi kinerja guru. Subjek penelitian ini adalah warga SMA Negeri 1 Bangli yaitu kepala sekolah, wakil kepala sekolah, guru beserta staf sekolah dan siswa yang ditentukan dengan menggunakan teknik purposive sampling. Pengumpulan data dalam penelitian ini dilakukan dengan teknik (1) Observasi; (2) Wawancara; (3) Kuesioner; (4) Pencatatan Dokumen. Data penelitian dianalisis dengan menggunakan model Milles dan Huberman yaitu reduksi data, penyajian data dan penarikan kesimpulan. Hasil penelitian menunjukkan bahwa (1) Pembatalan status RSBI yang ditetapkan oleh Mahkamah Konstitusi terhadap Pasal 50 Ayat (3) Undang-Undang Nomor 20 Tahun 2003 ternyata berpengaruh terhadap motivasi belajar siswa SMA Negeri 1 Bangli di mana terjadinya penurunan dilihat dari keaktifan siswa dalam kelas dan keaktifan dalam mengikuti kegiatan ekstrakurikuler dan olimpiade; (2) Dihapusnya status RSBI ternyata berdampak pada prestasi belajar siswa SMA Negeri 1 Bangli di mana telah bterjadi penurunan dilihat dari prestasi yang diraih di tingkat kabupaten, propinsi, nasional dan internasional setelah dihapusnya status RSBI; (3) Penghapusan status RSBI ternyata tidak berpengaruh terhadap prestasi kinerja guru di SMA Negeri 1 Bangli dilihat dari keaktifan guru dalam mengajar juga dalam mengarahkan, membimbing dan melatih siswa dalam mengikuti kegiatan ekstrakurikuler dan olimpiade.
\end{abstract}

Kata-kata kunci : RSBI, motivasi belajar, prestasi belajar, prestasi kinerja guru 


\begin{abstract}
This study aims at determining the impact of the abolition of RSBI status on (1) student's learning motivation; (2) student's learning achievements; (3) teacher's performance achievement at SMAN 1 Bangli. This research is a qualitative descriptive case study research strategy. The place of the research SMAN 1 Bangli that once beared the RSBI status. The object of this study was (1) student's learning motivation; (2) student's learning achievement; (3) achievement of teacher performance. The subjects were the community of SMAN 1 Bangli, i.e. principals, vice-principals, teachers and school staff as well as students who were determined by using purposive sampling technique. The collection of the data in this study was done by using (1) Observation; (2) Interview; (3) Questionnaire; and (4) Recording of Documents. The data were analyzed by using a model of Milles and Huberman, namely data reduction, data display and conclusion The results showed that (1) Abolition of RSBI status established by the Constitutional Court on Article 50 Paragraph (3) of Law No. 20 of 2003 was influential on students' learning motivation SMAN 1 Bangli where the decline occurred as seen from students activeness in the classroom and their activeness in extracurricular activities and in olympic games; (2) the abolition of RSBI status turned out to have an impact on student's learning achievement SMAN 1 Bangli where the decline occurred as seen from the achievement at the district, provincial, national and international level after the abolition of $\mathrm{RSBI}$; (3) the abolition of RSBI status did not affect the performance achievement of teacher at SMAN 1 Bangli as seen from the activeness of the teacher in teaching and also in directing, guiding and training students in participating in extracurricular activities and the Olympics.
\end{abstract}

Key words : RSBI, motivation to learn, academic achievement, teacher performance achievement. 


\section{PENDAHULUAN}

Dewasa ini kerap kali ditemukan masalah pendidikan yang menjadi topik utama. Pendidikan di Indonesia diharapkan dapat mempersiapkan peserta didik yang memiliki kualitas yang mampu bersaing di kancah Internasional serta mampu menjadi warga negara yang memiliki komitmen kuat dan konsisten untuk membanggakan negara serta mempertahankan Negara Kesatuan Republik Indonesia melalui bidang pendidikan. Bidang pendidikan sangat berperan penting dalam memajukan kesejahteraan kehidupan bangsa Indonesia. Untuk sekarang yang sedang hangat diperbincangkan adalah masalah sekolah yang bertaraf Internasional seperti Rintisan Sekolah Bertaraf Internasional (RSBI). Sekolah RSBI adalah sekolah negeri yang bertaraf Internasional.

Saat sekolah RSBI mulai dirintis, banyak siswa bersekolah di sekolah RSBI dan orang tua siswa berbondong-bondong menyekolahkan anaknya di sekolah tersebut. Para orang tua awalnya berpikir jika menyekolahkan anaknya di sekolah RSBI, anak-anak mereka akan mendapatkan pendidikan yang sangat berkualitas dan tidak kalah pamornya dengan sekolah internasional yang rata-rata di pegang oleh pihak swasta. Dengan bersekolah di sekolah RSBI maka siswa akan mendapatkan pendidikan yang umumnya juga sama dengan yang diberikan di sekolah internasional namun, sekolah RSBI merupakan sekolah negeri sehingga mereka diringankan dengan biaya yang tidak begitu mahal seperti di sekolah internasional pada umumnya. Siswa yang bersekolah di sekolah RSBI akan lebih termotivasi untuk belajar dan meraih prestasi.

Tidak hanya siswa di sekolah RSBI saja yang harus berprestasi, begitu juga dengan para guru yang mengajar di sekolah tersebut akan lebih termotivasi untuk meningkatkan prestasi mereka karena mereka tidak ingin kalah saing dengan sekolah regular pada umunya. Namun, kenyataannya pada saat ini praktik yang berjalan tidaklah seperti yang diharapkan. Banyak terjadi penyimpangan terhadap praktik dari penyelenggaraan sekolah RSBI tersebut. Setelah didirikannya sekolah RSBI membuat terjadinya beberapa kesenjangan. Orang yang mampu secara finansial namun kurang berprestasi justru dapat bersekolah di sekolah RSBI dan secara otomatis juga mendapatkan banyak dana dari Anggaran Pendapatan Belanja Daerah (APBD). Dengan begitu, banyak orang kaya yang bersekolah di sekolah RSBI. Padahal sekolah RSBI ditujukan terutama pada siswa berprestasi yang tidak mampu. Namun, dalam praktiknya pihak pengelola sekolah masih saja kurang memperhatikan hal tersebut. Padahal prestasi dalam hal ini sangatlah penting. Pembubaran RSBI alasannya karena RSBI merupakan kesalahan besar dalam pembangunan pendidikan nasional dan tidak sejalan dengan pembukaan UUD 45, yakni mencerdaskan kehidupan bangsa.

Dihapusnya RSBI merupakan bentuk penghilangan diskriminasi pendidikan di Indonesia. Konsep RSBI menjadi sekolah percontohan memang baik namun, pada pelaksanaannya justru menjadi ajang eksploitasi. Yang punya uang bisa mendapat pendidikan yang layak sedangkan rakyat yang kurang mampu tidak mendapat akses pendidikan yang memadai. Anak-anak orang miskin tetapi pintar, tidak dapat pelayanan dan kualitas baik dalam bidang pendidikan. Sesungguhnya program ini adalah program yang memalukan bangsa dan mengkhianati rakyat kecil. Ini bersifat diskriminatif terhadap rakyat kecil.

Begitu banyak masalah yang muncul dalam bidang pendidikan. Melihat kenyataan yang ada serta terjadi banyak kesenjangan dalam bidang pendidikan, tak pelak sekarang masalah yang timbul akibat adanya sekolah RSBI menjadi prioritas utama dalam bidang pendidikan. Dihapusnya status RSBI bisa saja mempengaruhi motivasi belajar dan prestasi belajar siswa serta prestasi kinerja guru di sekolah.

\section{METODE PENELITIAN}

\subsection{Jenis Penelitian}

Penelitian ini menggunakan jenis penelitian deskriptif kualitatif dengan pendekatan kualitatif serta strategi penelitian studi kasus. 


\subsection{Lokasi Penelitian}

Lokasi penelitian ini dilaksanakan di SMA Negeri 1 Bangli yang merupakan salah satu sekolah negeri di Kabupaten Bangli yang pernah menyandang status sebagai sekolah RSBI.

\subsection{Subjek Penelitian}

Subjek (responden) dalam penelitian ini adalah warga SMA Negeri 1 Bangli terdiri dari Kepala Sekolah, Wakil Kepala Sekolah, Guru dan Staf Sekolah serta siswa yang ditentukan dengan menggunakan teknik purposive sampling.

\subsection{Teknik Pengumpulan Data \\ 2.4.1. Metode Observasi}

Peneliti melakukan pengamatan yang kemudian melakukan pencatatan terhadap motivasi belajar siswa, prestasi belajar siswa dan prestasi kinerja guru di SMA Negeri 1 Bangli.

\subsubsection{Metode Wawancara}

Wawancara adalah proses memperoleh keterangan atau data untuk tujuan penelitian dengan cara tanya jawab, sambil bertatap muka antara pewawancara dengan responden dengan menggunakan alat yang dinamakan panduan wawancara (Syofian Siregar, 2011:130). Tujuan dalam wawancara ini adalah untuk mengetahui perkembangan motivasi belajar siswa, prestasi belajar siswa dan prestasi kinerja guru di SMA Negeri 1 Bangli.

\subsubsection{Metode Kuesioner}

Metode kuesioner yang digunakan adalah kuesioner terbuka. Kuesioner terbuka menurut Syofian Siregar (2011:133) merupakan angket atau pertanyaanpertanyaan yang diberikan kepada responden yang memberikan keleluasaan kepada responden untuk memberikan pendapat sesuai dengan keinginan mereka.

\subsubsection{Metode Pencatatan Dokumen}

Pencatatan dokumen merupakan suatu cara untuk memperoleh data yang dilakukan dengan cara pengumpulan segala macam dokumen serta mengadakan pencatatan secara sistematis. Hal ini untuk melengkapi data-data yang diperoleh serta memperkuat informasi yang diperoleh.

\subsection{Teknik Analisis Data}

Menurut Milles dan Huberman seperti yang dikutip oleh Agus Salim (Dalam Sofian Siregar, 2011:213) menyebutkan bahwa : ada tiga langkah pengolahan data kualitatif yakni, reduksi data (data reducion), penyajian data (data display), dan penarikan kesimpulan (conclusion drawing and verification).

\section{Hasil dan Pembahasan}

\subsection{Hasil Penelitian}

\subsubsection{Motivasi Belajar Siswa}

Motivasi belajar siswa dapat dilihat dari proses belajar siswa dalam kelas seperti keaktifan siswa dalam bertanya maupun berargumentasi saat proses belajar mengajar, dilihat dari pemanfaatan waktu belajar, juga dapat dilihat dari keaktifan siswa dalam mengikuti kegiatan ekstrakurikuler seperti olimpiade sains.

Proses belajar mengajar di dalam kelas setelah status RSBI dihapuskan menurut pendapat guru keaktifan siswa dalam kelas masih biasa saja, sama seperti saat SMA Negeri 1 Bangli masih menyandang status sekolah RSBI. Namun, jika dilihat dari peningkatan maupun penurunan, keaktifan siswa dalam proses belajar lebih banyak mengalami penurunan. Siswa nampak kurang semangat dan kurang aktif untuk bertanya maupun berargumen.

Kemudian menurut siswa dari beberapa siswa yang menjadi responden menyatakan bahwa saat mereka mulai bersekolah di SMA Negeri 1 Bangli yang dulu masih menyandang status RSBI, proses belajar mereka baik di sekolah maupun di rumah terasa lebih nyaman, apalagi di sekolah telah dilengkapi dengan sarana dan prasarana yang canggih dan memadai, dalam proses belajar mereka juga lebih aktif untuk berargumen karena merasa saingan di kelas sangat berat terlebih lagi jalur masuk di sekolah ini menggunakan tes seleksi yang sangat ketat. 
Selain karena saingan yang sangat berat, siswa dulu sangat aktif dalam proses belajar di kelas karena merasa gengsi, merasa termotivasi untuk tidak kalah saing dengan sekolah non-RSBI. Namun seiring dengan dihapusnya status RSBI, siswa mengalami sedikit penurunan keaktifan di kelas maupun keaktifan dalam mengikuti ajang bergengsi seperti olimpiade.

Adapun penurunan keaktifan siswa dalam kelas setelah dihapusnya status RSBI yaitu keaktifan siswa dalam bertanya di kelas khususnya dengan menggunakan Bahasa Inggris mengalami penurunan. Selain itu, penurunan keaktifan siswa di dalam kelas dikarenakan motivasi siswa yang menurun akibat adanya pengaruh secara psikologis setelah dihapusnya status RSBI, sehingga semangat kompetisi siswa menjadi menurun.

Hal itu dapat dilihat dari pendapat siswa terhadap keaktifan mereka saat belajar di kelas. Dari 45 orang siswa yang menjadi responden, 20 orang diantaranya menjawab bahwa mereka lebih senang atau sering diam karena tidak suka bertanya atau takut untuk bertanya dan hanya mendengarkan saja. 15 orang menjawab senang dan sering untuk bertanya jika ada hal yang belum dimengerti dan hal yang ingin ditanyakan mengenai pelajaran yang telah dibahas. Dan 10 orang lagi memberikan pernyataan seimbang antara diam mendengarkan saja ataupun bertanya di dalam kelas saat kegiatan belajar. Jadi, berdasarkan hal tersebut dapat dikatakan bahwa setelah dihapusnya status RSBI, motivasi belajar siswa di SMA Negeri 1 Bangli mengalami penurunan.

Lamanya siswa memanfaatkan waktu untuk belajar diluar jam sekolah atau jam pelajaran dapat menunjukkan seberapa besar motivasi siswa untuk belajar. Siswa masingmasing kelas memanfaatkan waktu belajar yang berbeda-beda dimulai dari rentang waktu 1-5 jam lebih tergantung dari situasi dan kondisi siswa yang bersangkutan. Namun, dari beberapa siswa yang diwawancarai, terlihat siswa di kelas unggulan yang memanfaatkan waktu belajar yang lebih banyak daripada siswa di kelas reguler lainnya. Selain waktu belajar tersebut, dapat dilihat pada saat jam istirahat, tidak banyak siswa yang memanfaatkan waktu istirahat dan jam kosong untuk membaca buku ke perpustakaan atau belajar di dalam kelas mempelajari yang sebelumnya sudah diberikan, siswa lebih memilih memanfaatkan waktu untuk ke kantin, mengobrol di depan kelas, bermain game dan memanfaatkan jaringan internet sekolah.

Motivasi belajar siswa juga dapat dilihat dari keaktifan siswa dalam mengikuti kegiatan ekstrakurikuler atau klub olimpiade sains. Kegiatan ekstrakurikuler di SMA Negeri 1 Bangli berjalan seperti biasa yang dilaksanakan setiap hari sabtu jam ke 7-8. Semua siswa dapat mengikuti kegiatan ekstrakurikuler. Ada banyak jenis ekstrakurikuler di SMA Negeri 1 Bangli seperti ektra PMR (Palang Merah Remaja), Drama (Teater), Tabuh, Mekidung (Kekawin), Basket, Bulutangkis, Sepak Bola, Voli, dan lain sebagainya. Selain itu, dalam kegiatan ekstrakurikuler juga ditambah dengan klub mata pelajaran yang diolimpiadekan seperti klub Fisika, Matematika, Kimia, Astronomi, Biologi, Ekonomi/Akuntansi, dan lain sebagainya, untuk mata pelajaran Bahasa terutama Bahasa Inggris ada yang dinamakan klub Debat Bahasa Inggris. Banyak jenis ekstrakurikuler di SMA Negeri 1 Bangli namun, hanya beberapa yang diminati siswa. Tidak semua kegiatan ekstrakurikuler banyak diminati siswa seperti halnya untuk klub debat Bahasa Inggris, peminatnya masih sangat rendah, minat siswa untuk mengikuti kegiatan klub debat Bahasa Inggris sangat rendah, terlebih lagi setelah status RSBI dihapuskan, karena tidak ada lagi program English Day dan English Area membuat siswa semakin rendah motivasinya untuk mengikuti kegiatan klub Debat Bahasa Inggris. Padahal ajang lomba Debat Bahasa Inggris sangatlah bergengsi, terlebih lagi pada tahun 2015 akan diadakan pasar bebas dunia, melalui debat Bahasa Inggris serta program English Day dan English Area dapat menunjukkan tingkat kemampuan siswa dalam menggunakan Bahasa Inggris guna mengikuti ajang pasar bebas tingkat internasional tersebut pada tahun 2015 nanti. 


\subsubsection{Prestasi Belajar Siswa}

Siswa SMA Negeri 1 Bangli dapat dikatakan siswa yang berprestasi baik di tingkat kabupaten, provinsi, nasional bahkan internasional. Prestasi siswa jika dilihat dari kelulusan nilai saat Ujian Nasional dapat dikatan masih sama yaitu dengan kelulusan $100 \%$ saat sebelum maupun setelah status RSBI dihapuskan. Namun, jika dilihat dari prestasi akademik dan non-akademik dari ajang perlombaan yang bergengsi prestasi siswa dapat dikatakan mengalami penurunan prestasi di tingkat provinsi, nasional dan internasional mengalami penurunan.

Selain prestasi dalam ajang perlombaan bergengsi baik akademik maupun non-akademik, ada satu lagi prestasi yang dapat dikatakan menurun setelah dihapusnya status RSBI di SMA Negeri 1 Bangli. Prestasi yang menurun itu adalah tidak adanya lagi atau tidak dilaksanakannya lagi pertukaran pelajar ke luar negeri, padahal ajang tersebut sangatlah bergengsi, terlebih lagi siswa yang sangat berprestasi mampu mengikuti pelajaran dan perkembangan di luar negeri terutama di negara-negara maju. Terlebih saat pulang ke sekolah asal akan memberikan pengalaman dan ilmu pengetahuan yang telah diperoleh di luar negeri sana. Setelah status RSBI dihapuskan, sekarang ajang seperti itu sudah tidak ada lagi, hanya ada pertukaran pelajar di tingkat nasional.

Selain itu, prestasi di tingkat internasional terakhir kalinya diraih oleh A.A. Esa Putra Kesava pada ajang lomba bergengsi yaitu "Idea of Change The World" yang mendapatkan emas di University Queensland Australia pada tahun 2013 beberapa saat sebelum status RSBI dihapuskan, dan setelah itu tidak ada lagi prestasi di tingkat internasional yang diraih oleh siswa-siswa SMA Negeri 1 Bangli.

\subsubsection{Prestasi Kinerja Guru}

Kinerja guru di SMA Negeri 1 Bangli sudah sangat baik. Hal ini dapat dilihat dari persiapan mengajar dengan perangkat guru dan perangkat mengajar yang dipersiapkan dan digunakan. Kinerja guru sangat baik dalam mengajar menggunakan media yang bervariasi, yang membuat siswa tidak jenuh saat kegiatan belajar mengajar dimulai, seperti halnya guru yang memanfaatkan fasilitas yang telah disediakan di sekolah yaitu dengan menggunakan media power point, LCD, Proyektor, speaker dan lain sebagainya untuk mata pelajaran tertentu. Selain itu dengan fasilitas yang telah ada tersebut memudahkan guru untuk siswa lebih mendengarkan saat guru menjelaskan dan membiasakan diri siswa untuk belajar mendengarkan jika ada tes yang berbentuk mendengarkan (listening). Selain itu, banyak guru yang aktif dalam mengajak, mengarahkan dan membimbing siswa untuk mengikuti kegiatan ekstrakurikuler ataupun mengikuti klub matapelajaran yang diolimpiadekan sesuai dengan bakat atau kegemaran siswa. Guru sudah sangat aktif dalam membimbing siswa dalam kegiatan ekstrakurikuler dan klub mata pelajaran yang diolimpiadekan maupun klub debat yang dilaksanakan serempak pada hari sabtu pada jamke 7-8. Kegiatan tersebut diikuti oleh siswa kelas $\mathrm{X}$ dan $\mathrm{XI}$, dan bagi siswa kelas XII tidak diwajibkan untuk mengikuti kegiatan ekstrakurikuler maupun klub matapelajaran atau klub debat, jadi siswa kelas XII boleh ikut serta ataupun tidak. Namun, keaktifan guru dalam mengarahkan dan membimbing siswa, masih ada siswa kelas XII yang mengikuti kegiatan ekstrakurikuler tersebut. Selain itu pula sebagian siswa kelas $\mathrm{X}$ dan $\mathrm{XI}$ juga masih aktif dalam mengikuti kegiatan ekstrakurikuler. Hal tersebut tidak luput dari peran serta kinerja guru dalam mengarahkan, membimbing, melatih dan mendidik siswa. Dari semua pendapat di atas maka dapat disimpulkan bahwa kinerja guru di SMA Negeri 1 Bangli baik sebelum maupun setelah status RSBI dihapuskan masih tetap bagus. Karena saat SMA Negeri 1 Bangli menjadi sekolah RSBI, guru-guru yang mengajar di sekolah ini sudah mulai merasa terpacu untuk dapat meningkatkan prestasi siswa dan itu juga merupakan komitmen guru untuk terus meningkatkan prestasi siswa. Jadi walaupun status RSBI pada SMA Negeri 1 Bangli sudah dihapuskan, kinerja guru di SMA Negeri 1 Bangli masih tetap bagus dan optimal. 
Guru sudah aktif dalam memberikan pembinaan rutin serta memberikan motivasi tentang arti penting pengalaman sebagai bentuk untuk ajang evaluasi kompetensi diri. Dimulai dari pemberitahuan bahwa jika lolos seleksi akan mendapat kemudahan saat mengikuti SNMPTN, seleksi minat dan bakat, pemilihan tiga siswa yang terbaik untuk mewakili sekolah. Selain itu, guru membimbing siswa yang mengikuti olimpiade dengan cara membahas soal bersama-sama, memberikan materi setingkat lebih tinggi dari sewajarnya, memberikan jam yang lebih banyak untuk latihan-latihan, kemudian dilanjutkan dengan pendalaman materi baik itu uji antar peserta maupun pendalaman materi yang sudah dipersiapkan. Pembinaan diadakan tiap minggu yaitu saat hari sabtu jam ke 7-8. Adapun saat pembinaan dihadirkan dosen dari luar sekolah yang akan membina siswa yang mengikuti olimpiade.

\subsection{Pembahasan}

Dari hasil penelitian di atas maka dapat dikatakan bahwa motivasi siswa untuk berkompetisi atau minat siswa untuk mengikuti kegiatan ekstrakurikuler terutama di bidang olimpiade dan debat Bahasa Inggris mengalami penurunan setelah dihapuskannya status RSBI. Siswa tidak memiliki semangat yang tinggi lagi seperti sejak sekolah masih menyandang status RSBI, karena saat sekolah masih menyandang status RSBI siswa merasa lebih bergengsi, memiliki gengsi yang lebih tinggi untuk mengikuti kompetisi-kompetisi. Baik itu di bidang akademik seperti kegiatan olimpiade dan debat Bahasa Inggris atau debat mata pelajaran yang lainnya maupun kompetisi dibidang non-akademik seperti kegiatan perlombaan dibidang seni dan olahraga. Penurunan motivasi tersebut karena adanya pengaruh dihapuskannya status RSBI terhadap psikologis siswa.

Dari hasil penelitian di atas dapat dikatakan bahwa keaktifan siswa di SMA Negeri 1 Bangli setelah status RSBI dihapuskan cenderung mengalami penurunan akibat adanya penurunan motivasi siswa karena dampak dari psikologis siswa yang terganggu dengan dihapusnya status RSBI.
Jadi, berdasarkan hal tersebut dapat dikatakan bahwa setelah dihapusnya status RSBI, motivasi belajar siswa di SMA Negeri 1 Bangli mengalami penurunan. Hal ini sejalan dengan pendapat Slameto (2003:55) bahwa sekurang-kurangnnya ada tujuh faktor yang tergolong ke dalam faktor psikologis yang mempengaruhi belajar. Faktor-faktor itu adalah : inteligensi, perhatian, minat, bakat, motif (motivasi), kematangan dan kelelahan. Maka dari itu karena adanya dampak terhadap psikologis siswa akibat dihapuskannya status RSBI mengakibatkan penurunan terhadap minat dan motivasi belajar siswa.

Setelah dihapusnya status RSBI di SMA Negeri 1 Bangli, siswa diharapkan agar tetap memiliki motivasi yang tinggi dalam belajar namun setelah dihapusnya status RSBI di SMA Negeri 1 Bangli ternyata mempengaruhi motivasi belajar siswa sehingga mengalami penurunan. Hal tersebut dapat dilihat dari penurunan keaktifan siswa dalam kegiatan belajar mengajar dan minat siswa dalam mengikuti kegiatan ekstrakurikuler terutama dalam bidang olimpiade.

Berdasarkan hasil penelitian di atas dapat dikatakan bahwa prestasi siswa setelah status RSBI dihapuskan mengalami penurunan, terutama di tingkat provinsi, nasional dan internasional. Karena untuk siswa yang mengikuti perlombaan di bidang akademik hanya mampu meraih juara di tingkat kabupaten. Selain itu pula setelah status RSBI dihapuskan sudah tidak ada lagi pertukaran pelajar yang paling berprestasi ke luar negeri, hanya ada pertukaran pelajar di tingkat nasional, jadi dapat juga dilihat dari hal tersebut bahwa setelah status RSBI dihapuskan prestasi siswa mengalami penurunan.

Hal ini sejalan dengan pendapat Slameto bahwa faktor yang dapat mempengaruhi prestasi belajar siswa salah satunya adalah faktor internal siswa. Dalam faktor internal terdapat faktor psikologis siswa yang salah satunya adalah motivasi. Motivasi belajar siswa dapat mempengaruhi prestasi belajar siswa. Menurut Slameto (2003:58) bahwa motif (motivasi) erat sekali 
hubungannya dengan tujuan yang akan dicapai (prestasi). Di dalam menentukan tujuan itu dapat disadari atau tidak, akan tetapi untuk mencapai tujuan itu perlu berbuat, sedangkan yang menjadi penyebab berbuat adalah motif (motivasi) itu sendiri sebagai daya penggerak/pendorongnya.

Berdasarkan hasil penelitian dari penelitian yang relevan dapat dikatakan bahwa siswa di sekolah RSBI dapat meraih prestasi dari tingkat provinsi hingga nasional, namun ada beberapa sekolah yang bisa meraih prestasi baik di bidang akademik maupun non akademik hingga di tingkat internasional. Hal ini sejalan dengan hasil penelitian di SMA Negeri 1 Bangli, dapat dikatakan bahwa pada saat SMA Negeri 1 Bangli masih menyandang status RSBI banyak prestasi yang telah dicapai baik di tingkat kabupaten hingga di tingkat internasional. Namun, setelah dihapusnya status RSBI di SMA Negeri 1 Bangli ternyata prestasi siswa mengalami penurunan di tingkat internasional, hanya mampu meraih prestasi di tingkat kabupaten dan provinsi.

Setelah dihapusnya status RSBI di SMA Negeri 1 Bangli, siswa diharapkan agar tetap memiliki prestasi yang tinggi hingga di tingkat internasional namun setelah dihapusnya status RSBI di SMA Negeri 1 Bangli ternyata mempengaruhi prestasi belajar siswa sehingga mengalami penurunan. Hal tersebut dapat dilihat dari penurunan prestasi siswa di tingkat nasional dan internasional. Siswa SMA Negeri 1 Bangli hanya mampu meraih prestasi di tingkat kabupaten dan provinsi.

Dari hasil penelitian di atas dapat dikatakan bahwa kinerja guru di SMA Negeri 1 Bangli baik sebelum maupun setelah status RSBI dihapuskan masih tetap baik dan kinerja guru tidak terpengaruh dengan dihapusnya status RSBI. Karena saat SMA Negeri 1 Bangli menjadi sekolah RSBI, guruguru yang mengajar di sekolah ini sudah mulai merasa terpacu untuk dapat meningkatkan prestasi siswa dan itu juga merupakan komitmen guru untuk terus meningkatkan prestasi siswa, jadi walaupun status RSBI pada SMA Negeri 1 Bangli sudah dihapuskan namun kinerja guru di SMA
Negeri 1 Bangli masih tetap baik terlebih lagi guru-guru SMA Negeri 1 Bangli sudah memiliki kompetensi guru yang sesuai dan profesional dalam mengemban tugas sebagai guru guna mencetak siswa-siswa yang berprestasi.

Guru sudah dapat dikatakan berprestasi, hal ini sejalan dengan pernyataan Djamarah (1994:19) bahwa prestasi adalah hasil dari suatu kegiatan yang telah dikerjakan, diciptakan, baik secara individual maupun kelompok. Prestasi tidak akan dihasilkan selama seseorang tidak melakukan suatu kegiatan.

Prestasi guru sama saja halnya dengan prestasi siswa, namun dalam hal ini lebih ditekankan pada keprofesionalitasan guru tersebut atau lebih menekankan pada kinerja guru itu sendiri dalam mengemban tugas menjadi seorang pengajar, pendidik dan pelatih. Bagaimana guru tersebut memberikan kesan yang baik terhadap anak didik sehingga anak didik berprestasi dan unggul dalam dunia pendidikan.

Menurut Djamarah (1994:34) bahwa kompetensi mutlak dimiliki guru sebagai kemampuan, kecakapan atau keterampilan dalam mengelola kegiatan pendidikan. Dengan demikian, kompetensi guru berarti pemilikan pengetahuan keguruan, dan pemilikan keterampilan serta kemampuan sebagai guru dalam melaksanakan tugasnya. Melalui kompetensi yang dimiliki guru itulah prestasi kinerja guru akan terlihat.

\section{Penutup \\ 4.1. Simpulan}

Berdasarkan deskripsi hasil penelitian dan pembahasan terhadap keseluruhan aspek yang menjadi fokus penelitian di atas, maka dapat disimpulkan sebagai berikut.

(1)Karena program RSBI telah dihapuskan oleh Mahkamah Konstitusi secara otomatis status RSBI juga terlepas dari SMA Negeri 1 Bangli. Dihapusnya status RSBI ternyata mempengaruhi motivasi belajar siswa SMA Negeri 1 Bangli. Siswa SMA Negeri 1 Bangli mengalami penurunan motivasi belajar yang dikarenakan adanya pengaruh terhadap psikologis siswa tentang sekolah yang sudah tidak lagi 
menyandang status RSBI dan tidak lagi memiliki gengsi yang lebih tinggi daripada sekolah-sekolah lainnya.

(2)Setelah dihapusnya status RSBI oleh Mahkamah Konstitusi ternyata mempengaruhi prestasi belajar sehingga mengalami penurunan. Hal ini dikarenakan motivasi belajar sangat berhubungan dengan prestasi belajar siswa. Motivasi belajar merupakan faktor internal dari prestasi belajar. Karena dalam diri siswa sudah tidak ada motivasi untuk belajar maupun berkompetisi maka hal itu akan mengakibatkan penurunan terhadap prestasi yang dapat diraih oleh siswa. Dihapusnya status RSBI dapat mempengaruhi prestasi belajar siswa di SMA Negeri 1 Bangli yaitu mengalami penurunan terhadap prestasi belajar siswa.

(3)Dihapusnya status RSBI tenyata tidak berpengaruh secara signifikan terhadap prestasi kinerja guru di SMA Negeri 1 Bangli. Karena guru sendiri dalam hal ini dari awal dan sampai akhir tetap berkomitmen untuk meningkatkan prestasi siswa walaupun siswa mengalami penurunan motivasi dan prestasi belajar setelah dihapusnya status RSBI oleh Mahkamah Konstitusi. Bukan hanya karena komitmen guru tetapi guru sendiri di SMA Negeri 1 Bangli sudah memiliki kompetensi yang harus dimiliki oleh seorang guru, jadi karena kompetensi yang dimiliki guru tersebut yang secara konsisten berusaha untuk terus meningkatkan kualitas (profesionalitas) guru, mengakibatkan guru tidak mengalami perubahan yang signifikan terhadap kinerja guru di SMA Negeri 1 Bangli. Jadi, dapat disimpulkan bahwa penghapusan RSBI tidak mempengaruhi prestasi kinerja guru di SMA Negeri 1 Bangli.

\subsection{Saran}

\section{(1) Bagi Siswa}

Siswa SMA Negeri 1 Bangli diharapkan walaupun sudah tidak ada lagi program seperti RSBI kedepannya namun harus tetap semangat dan termotivasi untuk berkompetisi dalam bidang pendidikan, karena kompetisi belajar tidak akan terhenti dengan dihapusnya status RSBI. Menjadi seorang siswa harus mampu termotivasi dan meraih prestasinya walaupun banyak faktor nantinya yang akan mempengaruhi.

(2) Bagi Guru

Dengan kompetensi yang harus dimiliki oleh seorang guru, diharapkan agar seluruh guru SMA Negeri 1 Bangli tetap berkomitmen untuk meningkatkan semangat, motivasi dan prestasi belajar siswa. Guru diharapkan mengajar dengan cara yang lebih menyenangkan yang sesuai dengan pembelajaran kooperatif ataupun pelajaran yang PAKEM. Dengan begitu dapat pula meningkatkan profesionalisme guru. Diharapkan setelah dihapusnya status RSBI kinerja guru harus masih tetap profesional dan tetap unggul dalam hal mengajar dan mencetak siswa berprestasi hingga ke tingkat internasional.

(3) Bagi Sekolah

SMA Negeri 1 Bangli diharapkan untuk tetap menjadi sekolah yang diminati banyak siswa dan menjadi sekolah unggulan di Kabupaten Bangli dengan kualitas sekolah dan kualitas pendidikan serta memiliki tenaga pendidik yang profesional. Menjadi sekolah yang mampu bersaing dengan sekolahsekolah negeri maupun swasta lainnya baik di Bali maupun di luar Bali.

(4) Bagi Pemerintah

Walaupun SMA Negeri 1 Bangli kini sudah tidak dipegang lagi oleh pemerintah pusat diharapkan pemerintah daerah Kabupaten Bangli masih tetap memperhatikan dan mengampu SMA Negeri 1 Bangli dengan memberikan perhatian dalam hal pengawasan sekolah, pembangunan maupun fasilitas atau sarana dan prasarana belajar dengan tidak mengesampingkan sekolah-sekolah lain yang ada di Kabupaten Bangli. Hal itu untuk mengurangi kecemburuan dalam bidang pendidikan dari sekolah-sekolah lain terhadap SMA Negeri 1 Bangli. Diharapkan agar pemerintah pusat dalam mengambil keputusan atau membuat peraturan agar sesuai dengan aspirasi rakyat, sesuai dengan keadaan masyarakat, dan tentunya membuat peraturan yang menjadikan negara ini lebih 
maju bukannya membuat peraturan yang dapat menimbulkan deskriminasi dalam pelaksanaannya. Dan dalam pelaksanaan terhadap peraturan yang telah dikeluarkan agar lebih diperketat sistem pelaksanaan dan pengawasannya.

\section{DAFTAR PUSTAKA}

Djamarah, Syaiful Bahri. 1994. Prestasi Belajar dan Kompetensi Guru. Surabaya: Usaha Nasional. 2006. Strategi Belajar Mengajar. Jakarta: Rineka Cipta

Emzir. 2013. Metodologi Penelitian Pendidikan Kuantitatif \& Kualitatif. Jakarta: RajaGrafindo Persada.

Fenny. 2011. "Pengaruh Rintisan Sekolah Bertaraf internasional" Tersedia pada http://fearlycute.blogspot.com/2011/04 /pengaruh-rintisan-sekolahberstandart.htm $\quad \mathrm{I} \mathrm{m}=1 \quad$ (diakses tanggal 16 Desember 2013)

Hamalik, Oemar, 2004. Proses Belajar Mengajar. Jakarta : Bumi Aksara

Hengkiriawan, 2013. "Prestasi Belajar". Tersedia pada http://hengkiriawan.blogspot.com/2012 /03/pengertian-prestasi-belajar.html (diakses tanggal 2 Juli 2013)

Kementerian Pendidikan Nasional. 2009. "Kebijakan Sekolah bertaraf Internasional". Tersedia pada http://dikdas.kemdiknas.go.id/docs/Ke bijakan-SBI.pdf (di akses tanggal 28 Oktober 2013)

Mady Oi. 2012. "Dampak Negatif dari Sekolah RSBI". Tersedia pada http://madyoi.blogspot.com/2012/06/ya ng-negatif-dari-sekolah-rsbi.html (di akses tanggal 28 Oktober 2013)

Purwanto, Ngalim. 2004. Psikologi Pendidikan. Bandung: Remaja Rosdakarya.

Roestiyah. 1994. Masalah Pengajaran Sebagai Suatu Sistem. Jakarta: Rineka Cipta.

Sardiman, 2009. Interaksi \& Motivasi Belajar Mengajar. Jakarta : Raja Grafindo Persada.
Siregar, Syofian. 2011. Statistika Deskriptif untuk Penelitian. Jakarta: Raja Grafindo Persada.

Slameto. 2003. Belajar dan Faktor-Faktor yang Mempengaruhinya. Jakarta: Rineka Cipta.

Tubas Media. 2013. "Latar Belakang Dibubarkannya RSBl". Tersedia pada http://www.tubasmedia.com/berita/rsbi sbi-dibubarkan-bertentangan-denganuud-45/ (di akses tanggal 28 Oktober 2013)

Wartapedia, 2013. "Keputusan MA tentang penghapusan gelar SBI/RSBI". Tersedia pada http://wartapedia.com/edukasi/progra m/10287-kemdikbud--hargai-putusanma-bubarkan-rsbi.html tanggal 14 Maret 2013)

Wikipedia. 2013. "Rintisan Sekolah Bertaraf Internasional". Tersedia pada http://id.wikipedia.org/wiki/Rintisan_Se kolah_Bertaraf_Internasional (di akses tanggal 28 Oktober 2013)

Wuradji dan Muhyadi. 2011. "Implementasi Program Rintisan Sekolah Bertaraf Internasional (RSBI) di Kota Yogyakarta". Tersedia pada http://staff.uny.ac.id/sites/default/files/ PENEL.RSBI\%202011_1.pdf (di akses tanggal 20 Desember 2013) 